\title{
Chryseobacterium chengduensis sp. nov. isolated from the air of captive giant panda enclosures in Chengdu, China ${ }^{* \#}$
}

\author{
Cai-fang $\mathrm{WEN}^{\S 1}$, Li-xin $\mathrm{XI}^{\S 1}$, Shan $\mathrm{ZHAO}^{1}$, Zhong-xiang $\mathrm{HAO}^{1}$, Lu LUO ${ }^{1}$, Hong LIAO $^{1}$, Zhen-rong CHEN $^{1}$, \\ Rong $\mathrm{SHE}^{1}$, Guo-quan $\mathrm{HAN}^{2}$, San-jie $\mathrm{CAO}^{1}$, Rui WU ${ }^{1}$, Qi-gui YAN ${ }^{\dagger 1}$, Rong $\mathrm{HOU}^{3}$ \\ ( ${ }^{1}$ College of Veterinary Medicine, Sichuan Agricultural University, Chengdu 611130, China) \\ $\left({ }^{2}\right.$ College of Food Science, Sichuan Agricultural University, Yaan 625014, China) \\ $\left({ }^{3}\right.$ Chengdu Research Base of Giant Panda Breeding, Chengdu 610081, China) \\ ${ }^{\dagger}$ E-mail: yanqigui@126.com
}

Received Sept. 5, 2015; Revision accepted Feb. 25, 2016; Crosschecked July 13, 2016

\begin{abstract}
A Gram-negative, aerobic, non-motile, rod-shaped bacterial strain, designated $25-1^{\top}$, was isolated from the air inside giant panda enclosures at the Chengdu Research Base of Giant Panda Breeding, China. Strain 25-1 ${ }^{\top}$ grew optimally at $\mathrm{pH} 7.0-8.0$, at $28-30{ }^{\circ} \mathrm{C}$ and in the presence of $\mathrm{NaCl}$ concentrations from $0.0 \%$ to $0.5 \%$. $16 \mathrm{~S}$ rRNA gene sequence analysis indicated that strain $25-1^{\top}$ belongs to the genus Chryseobacterium within the family Flavobacteriaceae and is related most closely to $C$. carnis $\mathrm{G} 81^{\top}$ (96.4\% similarity), C. lathyri RBA2-6 ${ }^{\top}$ (95.8\% similarity), and C. zeae JM1085 ${ }^{\top}(95.8 \%$ similarity). Its genomic DNA G+C molar composition was $36.2 \%$. The major cellular fatty acids were iso- $\mathrm{C}_{15: 0}(44.0 \%)$, iso- $\mathrm{C}_{17: 0} 3 \mathrm{OH}(19.8 \%)$ and $\mathrm{C}_{16: 1} \omega 7 \mathrm{c} / 16: 1 \omega 6 \mathrm{c}(12.7 \%)$. The only isoprenoid quinone was menaquinone 6 (MK-6). The major polar lipids were phosphatidylethanolamine, two unidentified amino lipids and two unidentified lipids. The DNA-DNA relatedness between strain $25-1^{\top}$ and $C$. lathyri RBA2- $6^{\top}$ was $38 \%$. Phenotypic, genotypic, and phylogenetic characteristics indicated that strain $25-1^{\top}$ is a novel member of the genus Chryseobacterium, for which the name C. chengduensis sp. nov. is proposed. The type strain is $25-1^{\top}\left(\right.$ CCTCC AB2015133 ${ }^{\top}=$ DSM $100396^{\top}$ ).
\end{abstract}

Key words: Chryseobacterium chengduensis, Giant panda, $16 \mathrm{~S}$ rRNA sequencing, Phylogenetic analysis, Strain $25-1^{\top}$ http://dx.doi.org/10.1631/jzus.B1500214

CLC number: S865

\section{Introduction}

The genus Chryseobacterium was first described by Vandamme et al. (1994) and assigned to the family Flavobacteriaceae of the phylum Bacteroidetes. Descriptions of novel Chryseobacterium species have been growing rapidly in recent years. Currently, the genus contains over 90 species with valid published

\footnotetext{
Corresponding author

$\S$ The two authors contributed equally to this work

* Project supported by the Chengdu Giant Panda Breeding Research Foundation (No. CPF2010-06) and the National Key Technology R \& D Program of China (No. 2012BAC01B06)

\# Electronic supplementary materials: The online version of this article (http://dx.doi.org/10.1631/jzus.B1500214) contains supplementary materials, which are available to authorized users

(1) ORCID: Qi-gui YAN, http://orcid.org/0000-0001-5721-2432

(C) Zhejiang University and Springer-Verlag Berlin Heidelberg 2016
}

names (http://www.bacterio.net/chryseobacterium.html). Chryseobacterium strains are widely distributed in aquatic and soil environments, plant rhizospheres, sediments, and food sources (Cho et al., 2010; Park et al., 2013; Loch and Faisal, 2014; Kämpfer et al., 2014a; 2014b; 2015a). However, to the best of our knowledge, no airborne representatives of the genus have yet been described. Some Chryseobacterium strains are significant as novel sources of bioactive compounds, such as antioxidants, prebiotics, or as sulfobacin and protease producers (Chaudhari et al., 2009; Wang et al., 2011; Kim H.S. et al., 2012). Moreover, some species, including $C$. indologenes, $C$. oranimense, and C. gleum, are opportunistic human pathogens implicated in nosocomial infections (Monteen et al., 2013; Lo and Chang, 2014; Nemli et al., 2015; Sharma et al., 2015). In veterinary medicine, no 
relevant Chryseobacterium species have been identified as a pathogen of domestic animals; nevertheless, numerous fish-associated species have been isolated from skin and muscle ulcerations, gill hemorrhage and hyperplasia, and from fish showing general signs of septicemia (Ilardi et al., 2009; Loch and Faisal, 2014). Cells are Gram-negative, strictly aerobic, non-motile, non-spore-forming, rods. They are pigmented yellow by flexirubin-type pigments with menaquinone 6 (MK-6) as the predominant respiratory quinone, branched-chain fatty acids (iso- $\mathrm{C}_{15: 0}$, iso- $\mathrm{C}_{17: 0} 3-\mathrm{OH}$, and iso- $\mathrm{C}_{17: 1} \omega 9 \mathrm{c}$ ) as the major fatty acids and a DNA $\mathrm{G}+\mathrm{C}$ content in the range from $29 \%$ to $39 \%$ (Kämpfer et al., 2009; Bernardet et al., 2010; Yang et al., 2015).

In this study, we investigated the cultivable bacterial community in the air of giant panda enclosures at the Chengdu Research Base of Giant Panda Breeding in Sichuan Province, located in southwestern China. Based on differences in colony morphology, 28 pure cultures were selected for $16 \mathrm{~S}$ rRNA gene sequencing and phylogenetic analysis. Species included members of the genera Micrococcus, Chryseobacterium, Leuconostoc, Staphylococcus, Pseudomonas, Kocuria, Bacillus, Exiguobacterium, Acinetobacter, Escherichia, Rothia, and Dietzia. The strain designated $25-1^{\mathrm{T}}$ was characterized using a polyphasic taxonomy approach, including evaluation of its morphological, biochemical, and phylogenetic characteristics. Unfortunately, C. carnis $\mathrm{G} 81^{\mathrm{T}}$ and $C$. zeae $\mathrm{JM} 1085^{\mathrm{T}}$ had not been released from culture collections at the time of these investigations and so were not included as reference strains. Therefore, all tests were performed on the new isolate and on $C$. lathyri RBA2- $6^{\mathrm{T}}$, which was acquired from the National Institute of Technology and Evaluation (NITE) Biological Resource Center (NBRC). The data obtained revealed that strain $25-1^{\mathrm{T}}$ should be assigned to the genus Chryseobacterium as the type strain of a novel species.

\section{Materials and methods}

\subsection{Culture conditions and phenotypic charac- teristics}

Strain $25-1^{\mathrm{T}}$ was isolated from the cultivable bacterial community in the air of a giant panda enclosure by exposing a petri dish containing tryptic soy agar (TSA, Difco, Leeuwarden, the Netherlands) medium for $15 \mathrm{~min}$. For further analysis, strain $25-1^{\mathrm{T}}$ was cultivated on Luria-Bertani (LB) agar (Difco) at $30{ }^{\circ} \mathrm{C}$. The presence of flexirubin type pigments was investigated using a $20 \%(0.2 \mathrm{~g} / \mathrm{ml}) \mathrm{KOH}$ solution according to the study of Bernardet et al. (2002). Gram staining was determined using the non-staining method described by Buck (1982). Cellular morphology, motility, and other physiological characteristics were evaluated as previously described (Wen et al., 2016). Cellular morphology was observed by light microscopy (Olympus; magnification $61000 \times$ ) and cell size was determined by transmission electron microscopy (H-600-A2; Hitachi, Tokyo, Japan) using cells from an exponentially growing culture. Motility tests were performed using LB broth with $0.3 \%(3 \mathrm{~g} / \mathrm{L})$ agar. Growth temperatures $(4,10,15,20,25,28,30$, $37,40,45$, and $\left.50^{\circ} \mathrm{C}\right)$ and $\mathrm{pH}(2.0-10.0$, at intervals of $1.0 \mathrm{pH}$ unit) were monitored during $7 \mathrm{~d}$ of incubation in LB broth as described by $\mathrm{Xu}$ and $\mathrm{Wu}$ (2005). $\mathrm{NaCl}$ tolerance was tested in $\mathrm{LN}$ medium (LB without $\mathrm{NaCl}$ ) supplemented with $0 \%, 0.5 \%, 1.0 \%-5.0 \%$ (at intervals of $1 \%)(1 \%=0.01 \mathrm{~g} / \mathrm{ml}) \mathrm{NaCl}$ during $7 \mathrm{~d}$ of incubation. Anaerobic growth was investigated by incubation in an anaerobic chamber (Mitsubishi Gas Chemical, Tokyo, Japan) at $30^{\circ} \mathrm{C}$ for $7 \mathrm{~d}$ on LB agar.

\subsection{Biochemical characteristics and microbial sensitivity test}

A number of key characteristics were tested using conventional procedures, as described by Smibert and Krieg (1994) and Skerman (1967), i.e., the production of catalase, oxidase, hydrogen sulphide and indole, and hydrolysis of Tween 80 , starch, and gelatin. Some strain $25-1^{\mathrm{T}}$ and C. lathyri RBA2-6 $6^{\mathrm{T}}$ biochemical reactions were detected using a bacterial biochemical trace kit (Hangzhou Microbial Reagent Co., Ltd., Hangzhou, China), which included the following substances: $\beta$-galactosidase, arginine decarboxylase, ornithine decarboxylase, nitrate reduction, mannose, adipic acid, arabinose, trehalose, cellobiose, lactose, salicin, and acetamide. The additional biochemical and physiological properties of strain $25-1^{\mathrm{T}}$ and C. lathyri RBA2- $6^{\mathrm{T}}$ were determined using the BD Phoenix ${ }^{\mathrm{TM}}-100$ automated microbiology system (Becton Dickinson, New Jersey, USA), according to the manufacturer's instructions. The biological principles of the Analytic Products INC (API) and Phoenix systems are similar (Wen et al., 2016), but the Phoenix system is automated and can 
handle a higher number of tests. Each negative identification (NID) panel contains two fluorescent positive control wells and 45 substrates (O'Hara, 2006). The sensitivity of strain $25-1^{\mathrm{T}}$ to various antibiotics was determined as previously described (Wen et al., 2016), by spreading bacterial suspensions on LB agar plates and applying filter paper discs containing the following antibiotics ( $\mu \mathrm{g}$ per disc): vancomycin (30), sulfamethoxazole (100), tetracycline (30), lincomycin (10), spectinomycin (100), kanamycin (30), furazolidone (100), streptomycin (10), erythromycin (15), trimesulf (25), ciprofloxacin (5), rifampicin (5), ampicillin (10), florfenicol (30), penicillin (10), gentamicin (10), amikacin (30), cephalothin (30), ceftazidime (30), doxycycline (30), cefotaxime (30), and enrofloxacin (5) (all obtained from Hangzhou Microbial Reagents). The strain was incubated in the presence of the antibiotics at $30^{\circ} \mathrm{C}$ for $24 \mathrm{~h}$.

\subsection{S rRNA sequencing and phylogenetic analysis}

The 16S rRNA gene of strain $25-1^{\mathrm{T}}$ was amplified by polymerase chain reaction (PCR) using two universal primers as described previously (Greisen et al., 1994), and the amplification products were sequenced by Invitrogen Biotechnology (Shanghai, China). The sequence was compared with sequences available in the EzTaxon Server (http://eztaxon-e. ezbiocloud.net; Kim O.S. et al., 2012) and GenBank database (http://blast.ncbi.nlm.nih.gov/Blast.cgi). The sequences of strain $25-1^{\mathrm{T}}$ and the type strains of published Chryseobacterium species were aligned using the Clustal_X program (Thompson et al., 1997). Phylogenetic analysis was performed using the MEGA 6.0 offline software (Tamura et al., 2013) and PHYML online web server (Guindon et al., 2005). Phylogenetic trees were constructed using the neighborjoining, maximum-likelihood (Felsenstein, 1981), and maximum-parsimony (Kluge and Farris, 1969) methods in the MEGA 6.0 program, with bootstrap analysis based on 1000 replicates (Felsenstein, 1985).

\subsection{Chemotaxonomic and genomic analyses}

The DNA G + C composition of strain $25-1^{\mathrm{T}}$ was determined using the thermal denaturation method (Mandel and Marmur, 1968) with Escherichia coli $\mathrm{K}-12$ as a control. Genomic DNA was extracted and purified using conventional procedures (Sambrook and Russell, 2001). Polar lipids of strain $25-1^{\mathrm{T}}$ were identified by two-dimensional thin-layer chromatog- raphy (TLC) according to the protocols of Tindall (1990). The respiratory quinones of strain $25-1^{\mathrm{T}}$ were extracted and analyzed by high performance liquid chromatography (HPLC) as described by Xie and Yokota (2003), using C. takakiae CGMCC1.13488 ${ }^{\mathrm{T}}$ as a reference strain. The whole cell fatty acids of strains $25-1^{\mathrm{T}}$ and C. lathyri RBA2- $6^{\mathrm{T}}$ grown on LB agar at $30^{\circ} \mathrm{C}$ for $48 \mathrm{~h}$ were analyzed using the Sherlock microbial identification system (MIDI) and identified using the MIDI software package Version 6.0 based on the TSBA6 6.00 database. The four above-mentioned analyses were performed at the China General Microbiological Culture Collection Center (CGMCC). Genomic DNA-DNA hybridizations were carried out between strain $25-1^{\mathrm{T}}$ and $C$. lathyri RBA2- $6^{\mathrm{T}}$ using the fluorometric method (Ezaki et al., 1989), at the Guangdong Microbiology Culture Center (GIMCC).

\section{Results and discussion}

\subsection{Morphological and physiological characteristics}

Cells of strain $25-1^{\mathrm{T}}$ were observed to be nonmotile, strictly aerobic, Gram-stain-negative, and rod-shaped (0.44-0.48 $\mu \mathrm{m}$ wide and 0.88-0.92 $\mu \mathrm{m}$ long; Fig. S1). Colonies on LB agar were nontransparent, yellow-pigmented, circular, and smooth with regular edges after $3 \mathrm{~d}$ of incubation at $30^{\circ} \mathrm{C}$. The non-fluorescent and non-diffusible yellow pigments belong to the flexirubin type. Cells grow in LN medium with $0 \%-2 \% \mathrm{NaCl}$ with an optimum concentration of $0 \%-0.5 \%$. Good growth occurs at $28-30{ }^{\circ} \mathrm{C}$ and no growth occurs below $10^{\circ} \mathrm{C}$ or above $40{ }^{\circ} \mathrm{C}$. Growth occurs at $\mathrm{pH} 6.0-9.0$ and optimally at $\mathrm{pH}$ 7.0-8.0. The characteristics of strain $25-1^{\mathrm{T}}$ and $C$. lathyri RBA2- $6^{\mathrm{T}}$ are shown in Tables 1 and 2. Strain $25-1^{\mathrm{T}}$ was able to use acetate, adonitol, and Dmannitol, but unable to use ornithine, sorbitol, or sucrose. In contrast to C. lathyri RBA2-6 ${ }^{\mathrm{T}}$, strain $25-1^{\mathrm{T}}$ was negative for L-glutamic acid-AMC, $\gamma$-glutamyl-NA, L-proline-NA, bis- $p$ NP-phosphate ( $p$ NP: $p$-nitropheno), $p$ NP- $\beta$-D-glucoside, and esculin hydrolysis.

\subsection{Phylogenetic analysis}

The 16S rRNA gene sequence (1401 bp) of strain $25-1^{\mathrm{T}}$ was obtained (GenBank accession number KP966546). Strain $25-1^{\mathrm{T}}$ showed less than $96.4 \%$ 
Table 1 Characteristics of strain $25-1^{\mathrm{T}}$ and $C$. lathyri RBA2-6 $^{\mathrm{T}}$ from conventional test

\begin{tabular}{|c|c|c|c|c|c|c|c|c|c|c|c|}
\hline Characteristics & 1 & 2 & Characteristics & 1 & 2 & Characteristics & 1 & 2 & Characteristics & 1 & 2 \\
\hline Catalase activity & + & + & Arginine decarboxylase & - & + & Nitrate reduction & - & - & Cellobiose & - & - \\
\hline Oxidase activity & + & + & Ornithine decarboxylase & + & - & Assimilation & & & Lactose & - & - \\
\hline Production & & & Degradation & & & Mannose & - & + & Salicin & - & - \\
\hline Indole & - & - & Starch & + & + & Adipic acid & - & - & Acetamide & - & - \\
\hline $\mathrm{H}_{2} \mathrm{~S}$ & - & - & Tween 80 & + & + & Arabinose & - & - & & & \\
\hline$\beta$-Galactosidase & - & - & Gelatin & - & + & Trehalose & - & - & & & \\
\hline
\end{tabular}

1: strain $25-1^{\mathrm{T}} ; 2$ : strain C. lathyri $\mathrm{RBA} 2-6^{\mathrm{T}}$;-: negative; +: positive. Data are from this study unless otherwise stated

Table 2 Characteristics of strain $25-1^{\mathrm{T}}$ and C. lathyri RBA2-6 ${ }^{\mathrm{T}}$ from Phoenix system

\begin{tabular}{|c|c|c|c|c|c|c|c|c|}
\hline Characteristics & 1 & 2 & Characteristics & 1 & 2 & Characteristics & 1 & 2 \\
\hline Hydrolysis & & & Bis- $p$ NP-phosphate & - & + & Sucrose & - & - \\
\hline Arginine-arginine-AMC & + & + & $\gamma$-Glutamyl-NA & - & + & Acetate & + & + \\
\hline Glycine-proline-AMC & + & + & Urea & - & - & Adonitol & + & + \\
\hline Glycine-AMC & + & + & Esculin & - & + & Citrate & + & + \\
\hline Glutaryl-glycine-arginine-AMC & + & + & Utilization & & & Galacturonic acid & - & - \\
\hline L-Arginine-AMC & + & + & D-Mannitol & + & + & L-Arabinose & - & - \\
\hline L-Glutamic acid-AMC & - & + & Tiglic acid & + & + & Malonate & + & + \\
\hline L-Leucine-AMC & + & + & $\beta$-Allose & - & - & L-Rhamnose & - & - \\
\hline L-Phenylalanine-AMC & + & + & $\beta$-Gentiobiose & - & - & Methyl- $\beta$-glucoside & - & - \\
\hline L-Proline-AMC & - & - & $\alpha$-Ketoglutaric acid & + & + & Maltulose & - & - \\
\hline L-Pyroglutamic acid-AMC & + & - & Dextrose & - & - & $N$-acetyl-galactosamine & - & - \\
\hline L-Tryptophan-AMC & + & + & D-Fructose & - & - & $N$-acetyl-glucosamine & - & - \\
\hline Lysine-alanine-AMC & + & + & D-Galactose & - & - & Ornithine & - & - \\
\hline L-Proline-NA & - & + & D-Gluconic acid & - & - & Resistance & & \\
\hline$p N P-\beta$-D-glucoside & - & + & D-Melibiose & - & - & Polymyxin B & + & + \\
\hline $\begin{array}{l}\text { 4MU- } N \text {-acetyl- } \beta \text {-D- } \\
\text { glucosaminide }\end{array}$ & + & + & Sorbitol & - & - & Colistin & + & + \\
\hline
\end{tabular}

1: strain $25-1^{\mathrm{T}}$; 2 : strain C. lathyri RBA2-6 ${ }^{\mathrm{T}}$; AMC: 7-amido-4-methylcoumarin; MU: methylumbelliferyl; $p \mathrm{NP}$ : $p$-nitropheno; -: negative;

$+:$ positive. Data are from this study unless otherwise stated

sequence similarity to the type strains of all recognized species in the genus Chryseobacterium. The highest 16S rRNA sequence similarity was found with C. carnis NCTC $13525^{\mathrm{T}}$ (96.4\%) (Holmes et al., 2013), followed by C. lathyri RBA2-6 ${ }^{\mathrm{T}}(95.8 \%), C$. zeae $\mathrm{JM}_{1085^{\mathrm{T}}}$ (95.8\%) (Kämpfer et al., 2014b), C. shigense GUM kaji ${ }^{\mathrm{T}}(95.8 \%)$ (Shimomura et al., 2005), C. gwangjuense THG A-18 $8^{\mathrm{T}}(95.7 \%)$ (Park et al., 2013), and C. carnipullorum 9-R $23581^{\mathrm{T}}(95.7 \%)$ (Charimba et al., 2013), as determined using the EzTaxon server 2.1. Strain $25-1^{\mathrm{T}}$ was included in a cluster containing the type strains of $C$. carnis and $C$. chaponense, forming a distinct phylogenetic lineage within the genus Chryseobacterium in the neighborjoining phylogenetic tree (Fig. 1). The phylogenetic position was also supported by the maximumparsimony and maximum-likelihood trees.

\subsection{Chemotaxonomic and genomic characteristics}

The cellular fatty acids of strain $25-1^{\mathrm{T}}$ and $C$. lathyri RBA2- $6^{\mathrm{T}}$ analyzed under the same conditions are shown in Table 3. The predominant fatty acids of strain $25-1^{\mathrm{T}}(\geq 5 \%)$ were iso- $\mathrm{C}_{15: 0}(44.0 \%)$, iso- $\mathrm{C}_{17: 0}$ $3 \mathrm{OH}(19.8 \%)$, summed feature $3\left(\mathrm{C}_{16: 1} \omega 7 \mathrm{c}\right.$ and/or $\left.\mathrm{C}_{16: 1} \omega 6 \mathrm{c}, 12.7 \%\right)$ and summed feature 9 (10-methyl $\mathrm{C}_{16: 0}$ and/or iso- $\mathrm{C}_{17: 1} \omega 9 \mathrm{c}, 7.8 \%$ ). Minor amounts of anteiso- $\mathrm{C}_{15: 0}(1.4 \%)$, iso- $\mathrm{C}_{16: 0}(1.8 \%)$, iso- $\mathrm{C}_{15: 0} 3 \mathrm{OH}$ (3.9\%), iso- $\mathrm{C}_{16: 0} 3 \mathrm{OH}(2.0 \%)$, and $\mathrm{C}_{16: 0} 3 \mathrm{OH}(1.2 \%)$ were also detected. The presences of major fatty acids, namely iso- $\mathrm{C}_{15: 0}$, iso- $\mathrm{C}_{17: 0} 3 \mathrm{OH}$ and iso- $\mathrm{C}_{17: 1} \omega 9 \mathrm{c}$, are in accordance with the placement of strain $25-1^{\mathrm{T}}$ in the genus Chryseobacterium ( $\mathrm{Li}$ and $\mathrm{Zhu}, 2012$; Kämpfer et al., 2015b). However, strain $25-1^{\mathrm{T}}$ could be readily distinguished from $C$. lathyri by the presence 


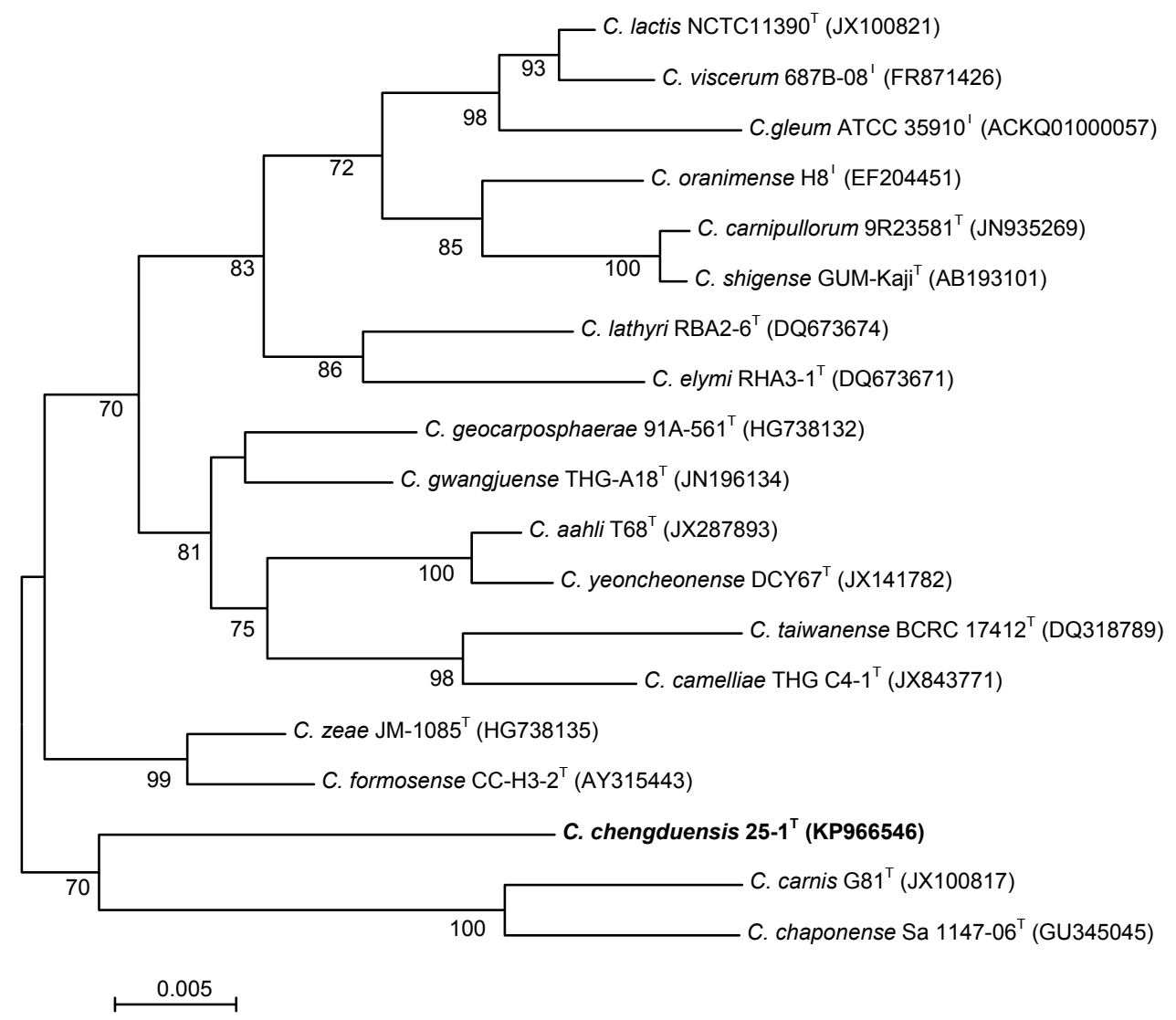

Fig. 1 Phylogenetic tree showing the relationship between strain $25-1^{\mathrm{T}}$ and the type strains of a selection of recognized Chryseobacterium species constructed by the neighbor-joining method based on their 16S rRNA gene sequences GenBank accession numbers are shown in parentheses. Numbers indicate percentages of occurrence of branch points in 1000 bootstrapped trees. The bar is $0.5 \%$ in the legend and 0.005 on the tree

Table 3 Cellular fatty acid content of strain $25-1^{\mathrm{T}}$ and C. lathyri RBA2-6 ${ }^{\mathrm{T}}$

\begin{tabular}{|c|c|c|}
\hline \multirow{2}{*}{ Fatty acid } & \multicolumn{2}{|c|}{ Content (\%) } \\
\hline & Strain 1 & Strain 2 \\
\hline iso- $\mathrm{C}_{15: 0}$ & 44.0 & 53.5 \\
\hline anteiso- $\mathrm{C}_{15: 0}$ & 1.4 & 1.8 \\
\hline iso- $\mathrm{C}_{15: 1} \mathrm{~F}$ & ND & 1.4 \\
\hline iso- $\mathrm{C}_{16: 0}$ & 1.8 & TR \\
\hline $\mathrm{C}_{16: 0}$ & TR & 1.8 \\
\hline iso- $\mathrm{C}_{15: 0} 3 \mathrm{OH}$ & 3.9 & 5.0 \\
\hline iso- $\mathrm{C}_{16: 0} 3 \mathrm{OH}$ & 2.0 & 1.5 \\
\hline $\mathrm{C}_{16: 0} 3 \mathrm{OH}$ & 1.2 & ND \\
\hline iso- $\mathrm{C}_{17: 0} 3 \mathrm{OH}$ & 19.8 & ND \\
\hline iso- $\mathrm{C}_{17: 0}$ & ND & 1.9 \\
\hline Summed feature $3^{\mathrm{a}}$ & 12.7 & 10.7 \\
\hline Summed feature $9^{a}$ & 7.8 & 18.0 \\
\hline
\end{tabular}

Strain 1: C. chengduensis sp. nov. $25-1^{\mathrm{T}}$; Strain 2: C. lathyri RBA2- $6^{\mathrm{T}}$. All data are from this study. Fatty acids that represented $<1.0 \%$ of the total in both strains are not shown. ND: not detected; TR: traces (i.e. $<1.0 \%)$. ${ }^{\text {a }}$ Summed features are groups of two or three fatty acids that cannot be separated by the Microbial Identification System. Summed feature 3 consisted $\mathrm{C}_{16 \cdot 1} \omega 7 \mathrm{c}$ and/or $\mathrm{C}_{16: 1} \omega 6 \mathrm{c}$; summed feature 9 consisted of 10-methyl $\mathrm{C}_{16: 0}$ and/or iso- $\mathrm{C}_{17: 1} \omega 9 \mathrm{c}$ of a high amount of iso- $\mathrm{C}_{17: 0} 3 \mathrm{OH}$ and a significantly lower amount of summed feature 9 . The discrepancies noted in the fatty acid composition of $C$. lathyri RBA2 $-6^{\mathrm{T}}$ as determined in this study compared to the data reported in the original description (Cho et al., 2010) may be due to differences in the fatty acid extraction methods, types of gas chromatography, or the culture media used. The isoprenoid quinone of strain $25-1^{\mathrm{T}}$ was MK-6, which is characteristic of all members of the family Flavobacteriaceae (Kämpfer et al., 2009). The polar lipids of strain $25-1^{\mathrm{T}}$ were phosphatidylethanolamine (PE), two unidentified amino lipids and two unidentified lipids (Fig. 2), which is in line with other recognized species of the genus Chryseobacterium (Kämpfer et al., 2015a). The DNA $\mathrm{G}+\mathrm{C}$ molar content of strain $25-1^{\mathrm{T}}$ was $36.2 \%$. This value is within the range reported for Chryseobacterium species (Bernardet et al., 2010; Montero-Calasanz et al., 2014). The mean DNADNA relatedness between strain $25-1^{\mathrm{T}}$ and C. lathyri 


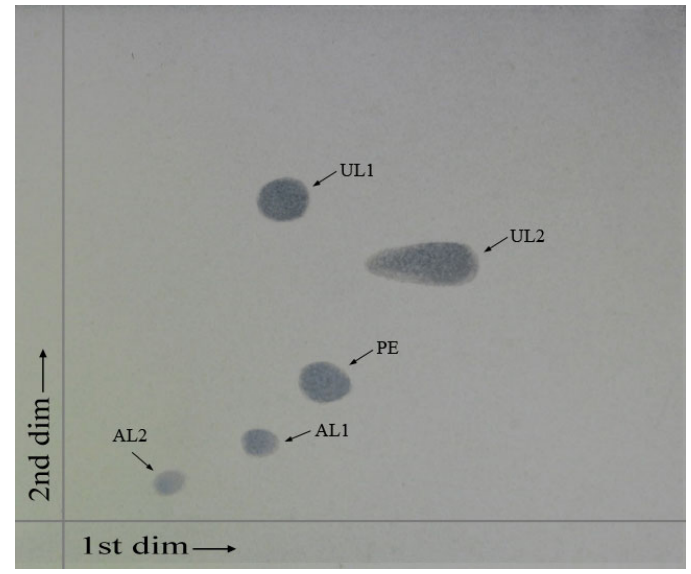

Fig. 2 Total polar lipid analysis of strain Chryseobacterium chengduensis $25-1^{\mathrm{T}}$ carried out by two-dimensional thinlayer chromatography (TLC)

Ascending solvent system: 1st dimension: chloroform/ methanol/water $(65: 25: 4, \mathrm{v} / \mathrm{v})$; 2nd dimension: chloroform/ methanol/acetic acid/water (80:12:15:4, v/v). Molybdatophosphoric acid was applied for the detection of polar lipids. PE, phosphatidylethanolamine; AL1 and AL2, unidentified amino lipids; UL1 and UL2, unidentified lipids

RBA2-6 ${ }^{\mathrm{T}}$ was $38 \%$. This is clearly far below the $70 \%$ threshold value that is generally used for prokaryotic species delineation (Stackebrandt et al., 2002).

\section{Conclusions}

The physiological, chemotaxonomic, and phylogenetic analyses conducted in this study show that strain $25-1^{\mathrm{T}}$ exhibits the main properties of the genus Chryseobacterium but can be differentiated from the closely related type strain, C. lathyri RBA2 $-6^{\mathrm{T}}$. The distinctiveness of strain $25-1^{\mathrm{T}}$ is sufficient to categorize the isolate as a member of a species that is distinguished from the published Chryseobacterium species. The low $16 \mathrm{~S}$ rRNA gene sequence similarity with all other described Chryseobacterium species supports the description of strain $25-1^{\mathrm{T}}$ as a member of a new Chryseobacterium species for which we propose the name $C$. chengduensis sp. nov. (cheng.du. en'sis. N.L. fem. adj. chengduensis pertaining to Chengdu in Sichuan Province, China, where the type strain was isolated). Cells of strain $25-1^{\mathrm{T}}$ are nonmotile, strictly aerobic, Gram-stain-negative, and rodshaped (0.44-0.48 $\mu \mathrm{m}$ wide and 0.88-0.92 $\mu \mathrm{m}$ long). Colonies on LB agar are non-transparent, yellow- pigmented, circular, and smooth with regular edges after $3 \mathrm{~d}$ of incubation at $30^{\circ} \mathrm{C}$. The non-fluorescent and non-diffusible yellow pigments belong to the flexirubin type. Cells grow in LN medium with $0 \%-2 \% \mathrm{NaCl}$ with an optimum concentration of $0 \%-0.5 \%$. Optimal growth occurs at $28-30^{\circ} \mathrm{C}$ and no growth occurs below $10{ }^{\circ} \mathrm{C}$ or above $40{ }^{\circ} \mathrm{C}$. Growth occurs at $\mathrm{pH}$ 6.0-9.0 and optimally at $\mathrm{pH}$ 7.0-8.0. Catalase and oxidase are produced, but not indole or $\mathrm{H}_{2} \mathrm{~S}$. Starch and Tween 80 are degraded but not gelatin. Nitrate is not reduced to nitrite. Acid is not produced from salicin, acetamide, mannose, $\beta$ galactosidase, trehalose, cellobiose, arabinose, and lactose. It is negative for adipic acid and arginine decarboxylase, and positive for the production of ornithine decarboxylase. In the Phoenix system, it is positive for arginine-arginine-AMC, glycine-prolineAMC, glycine-AMC, glutaryl-glycine-arginine-AMC, L-arginine-AMC, L-leucine-AMC, L-phenylalanineAMC, L-pyroglutamic acid-AMC, L-tryptophan-AMC, lysine-alanine-AMC, acetate, adonitol, citrate, colistin, D-mannitol, $\alpha$-ketoglutaric acid, malonate, tiglic acid, polymyxin $\mathrm{B}$, and $4 \mathrm{MU}-N$-acetyl- $\beta$-D-glucosaminide. It is sensitive to vancomycin, tetracycline, rifampicin, ciprofloxacin, florfenicol, doxycycline, amikacin, enrofloxacin, cefotaxime, ceftazidime, furazolidone, and trimesulf, but resistant to kanamycin, spectinomycin, erythromycin, cephalothin, sulfamethoxazole, lincomycin, streptomycin, ampicillin, penicillin, and gentamicin. The major cellular fatty acids are iso- $\mathrm{C}_{15: 0}$, iso- $\mathrm{C}_{17: 0} 3 \mathrm{OH}$, summed feature $3\left(\mathrm{C}_{16: 1} \omega 7 \mathrm{c}\right.$ and/or $\left.\mathrm{C}_{16: 1} \omega 6 \mathrm{c}\right)$ and summed feature 9 (10-methyl $\mathrm{C}_{16: 0}$ and/or iso- $\left.\mathrm{C}_{17: 1} \omega 9 \mathrm{c}\right)$. The only isoprenoid quinone detected was MK-6. The DNA G+C molar content was $36.2 \%$. The major polar lipids are phosphatidylethanolamine, two unidentified amino lipids and two unidentified lipids.

The type strain, $25-1^{\mathrm{T}}\left(\mathrm{CCTCC} \mathrm{AB} 2015133^{\mathrm{T}}=\right.$ DSM $100396^{\mathrm{T}}$ ), was isolated from the air inside giant panda enclosures at the Chengdu Research Base of Giant Panda Breeding in Sichuan Province, China.

\section{Compliance with ethics guidelines}

Cai-fang WEN, Li-xin XI, Shan ZHAO, Zhong-xiang HAO, Lu LUO, Hong LIAO, Zhen-rong CHEN, Rong SHE, Guo-quan HAN, San-jie CAO, Rui WU, Qi-gui YAN, and Rong HOU declare that they have no conflict of interest.

This article does not contain any studies with human or animal subjects performed by any of the authors. 


\section{References}

Bernardet, J.F., Nakagawa, Y., Holmes, B., 2002. Proposed minimal standards for describing new taxa of the family Flavobacteriaceae and emended description of the family. Int. J. Syst. Evol. Microbiol., 52(3):1049-1070. http://dx.doi.org/10.1099/00207713-52-3-1049

Bernardet, J.F., Hugo, C.J., Bruun, B., 2010. Chryseobacterium Vandamme Bernardet, Segers, Kersters and Holmes 1994, 829VP. In: Krieg, N.R., Staley, J.T., Brown, D.R. (Eds.), Bergey's Manual ${ }^{\circledR}$ of Systematic Bacteriology, 2nd Ed., Springer New York, p.180-196. http://dx.doi.org/10.1007/978-0-387-68572-4

Buck, J.D., 1982. Nonstaining (KOH) method for determination of Gram reactions of marine bacteria. Appl. Environ. Microbiol., 44(4):992-993.

Charimba, G., Jooste, P., Albertyn, J., et al., 2013. Chryseobacterium carnipullorum sp. nov., isolated from raw chicken. Int. J. Syst. Evol. Microbiol., 63(Pt 9):3243-3249. http://dx.doi.org/10.1099/ijs.0.049445-0

Chaudhari, P.N., Wani, K.S., Chaudhari, B.L., et al., 2009. Characteristics of sulfobacin A from a soil isolate Chryseobacterium gleum. Appl. Biochem. Biotechnol., 158(1):231-241. http://dx.doi.org/10.1007/s12010-008-8417-7

Cho, S.H., Lee, K.S., Shin, D.S., et al., 2010. Four new species of Chryseobacterium from the rhizosphere of coastal sand dune plants, Chryseobacterium elymi sp. nov., Chryseobacterium hagamense sp. nov., Chryseobacterium lathyri sp. nov. and Chryseobacterium rhizosphaerae sp. nov. Syst. Appl. Microbiol., 33(3):122-127. http://dx.doi.org/10.1016/j.syapm.2009.12.004

Ezaki, T., Hashimoto, Y., Yabuuchi, E., 1989. Fluorometric deoxyribonucleic acid-deoxyribonucleic acid hybridization in microdilution wells as an alternative to membrane filter hybridization in which radioisotopes are used to determine genetic relatedness among bacterial strains. Int J. Syst. Bacteriol., 39(3):224-229. http://dx.doi.org/10.1099/00207713-39-3-224

Greisen, K., Loeffelholz, M., Purohit, A., et al., 1994. PCR primers and probes for the 16S rRNA gene of most species of pathogenic bacteria, including bacteria found in cerebrospinal fluid. J. Clin. Microbiol., 32(2):335-351.

Felsenstein, J., 1981. Evolutionary trees from DNA sequences: a maximum likelihood approach. J. Mol. Evol., 17(6): 368-376. http://dx.doi.org/10.1007/BF01734359

Felsenstein, J., 1985. Confidence limits on phylogenies: an approach using the bootstrap. Evolution, 39(4):783-791. http://dx.doi.org/10.2307/2408678

Guindon, S., Lethiec, F., Duroux, P., et al., 2005. PHYML Online - a web server for fast maximum likelihood-based phylogenetic inference. Nucleic Acids Res., 33(Suppl. 2): W557-W559. http://dx.doi.org/10.1093/nar/gki352

Holmes, B., Steigerwalt, A.G., Nicholson, A.C., 2013. A DNA-DNA hybridization study of strains of Chryseo- bacterium, Elizabethkingia, Empedobacter and of other usually indole-producing non-fermenters of CDC groups IIc, IIe, IIh and IIi, all from mostly human clinical sources and proposals of Chryseobacterium bernardetii sp. nov., Chryseobacterium carnis sp. nov., Chryseobacterium lactis sp. nov., Chryseobacterium nakagawai sp. nov., and Chryseobacterium taklimakanense comb. nov. Int. J. Syst. Evol. Microbiol., 63(Pt 12):4639-4662.

http://dx.doi.org/10.1099/ijs.0.054353-0

Ilardi, P., Fernández, J., Avendaño-Herrera, R., 2009. Chryseobacterium piscicola sp. nov., isolated from diseased salmonid fish. Int. J. Syst. Evol. Microbiol., 59(12): 3001-3005.

http://dx.doi.org/10.1099/ijs.0.007021-0

Kämpfer, P., Vaneechoutte, M., Lodders, N., et al., 2009. Description of Chryseobacterium anthropi sp. nov. to accommodate clinical isolates biochemically similar to Kaistella koreensis and Chryseobacterium haifense, proposal to reclassify Kaistella koreensis as Chryseobacterium koreense comb. nov. and emended description of the genus Chryseobacterium. Int. J. Syst. Evol. Microbiol., 59(10):2421-2428. http://dx.doi.org/10.1099/ijs.0.008250-0

Kämpfer, P., Poppel, M.T., Wilharm, G., 2014a. Chryseobacterium gallinarum sp. nov., isolated from a chicken, and Chryseobacterium contaminans sp. nov., isolated as a contaminant from a rhizosphere sample. Int. J. Syst. Evol. Microbiol., 64(Pt 4):1419-1427. http://dx.doi.org/10.1099/ijs.0.058933-0

Kämpfer, P., McInroy, J.A., Glaeser, S.P., 2014b. Chryseobacterium zeae sp. nov., Chryseobacterium arachidis $\mathrm{sp}$. nov., and Chryseobacterium geocarposphaerae sp. nov. isolated from the rhizosphere environment. Antonie van Leeuwenhoek, 105(3):491-500. http://dx.doi.org/10.1007/s10482-013-0101-4

Kämpfer, P., Busse, H.J., McInroy, J.A., et al., 2015a. Chryseobacterium arachidiradicis sp. nov. isolated from the geocarposphere (soil around the peanut) of very immature peanuts (Arachis hypogaea). Int. J. Syst. Evol. Microbiol., 65(7):2179-2186. http://dx.doi.org/10.1099/ijs.0.000237

Kämpfer, P., Trček, J., Skok, B., et al., 2015b. Chryseobacterium limigenitum sp. nov., isolated from dehydrated sludge. Antonie van Leeuwenhoek, 107(6):1633-1638. http://dx.doi.org/10.1007/s10482-015-0434-2

Kim, H.S., Sang, M.K., Jung, H.W., et al., 2012. Identification and characterization of Chryseobacterium wanjuense strain KJ9C8 as a biocontrol agent of Phytophthora blight of pepper. Crop Prot., 32:129-137. http://dx.doi.org/10.1016/j.cropro.2011.10.018

Kim, O.S., Cho, Y.J., Lee, K., et al., 2012. Introducing EzTaxon-e: a prokaryotic 16S rRNA gene sequence database with phylotypes that represent uncultured species. Int. J. Syst. Evol. Microbiol., 62(Pt 3):716-721. http://dx.doi.org/10.1099/ijs.0.038075-0

Kluge, A.G., Farris, J.S., 1969. Quantitative phyletics and the 
evolution of anurans. Syst. Zool., 18(1):1-32.

http://dx.doi.org/10.2307/2412407

Li, Z., Zhu, H., 2012. Chryseobacterium vietnamense sp. nov., isolated from forest soil. Int. J. Syst. Evol. Microbiol., 62(Pt 4):827-831.

http://dx.doi.org/10.1099/ijs.0.027201-0

Lo, H.H., Chang, S.M., 2014. Identification, characterization, and biofilm formation of clinical Chryseobacterium gleum isolates. Diagn. Micr. Infec. Dis., 79(3):298-302. http://dx.doi.org/10.1016/j.diagmicrobio.2014.01.027

Loch, T.P., Faisal, M., 2014. Chryseobacterium aahli sp. nov., isolated from lake trout (Salvelinus namaycush) and brown trout (Salmo trutta), and emended descriptions of Chryseobacterium ginsenosidimutans and Chryseobacterium gregarium. Int. J. Syst. Evol. Microbiol., 64(Pt 5): 1573-1579.

http://dx.doi.org/10.1099/ijs.0.052373-0

Mandel, M., Marmur, J., 1968. Use of ultraviolet absorbance temperature profile for determining the guanine plus cytosine content of DNA. Methods Enzymol., 12(Pt B): 195-206. http://dx.doi.org/10.1016/0076-6879(67)12133-2

Monteen, M.R., Ponnapula, S., Wood, G.C., et al., 2013. Treatment of Chryseobacterium indologenes ventilatorassociated pneumonia in a critically Ill trauma patient. Ann. Pharmacother., 47(12):1736-1739. http://dx.doi.org/10.1177/1060028013508745

Montero-Calasanz, M., Göker, M., Rohde, M., et al., 2014. Chryseobacterium oleae sp. nov., an efficient plant growth promoting bacterium in the rooting induction of olive tree (Olea europaea L.) cuttings and emended descriptions of the genus Chryseobacterium, C. daecheongense, C. gambrini, C. gleum, C. joostei, C. jejuense, C. luteum, C. shigense, $C$. taiwanense, $C$. ureilyticum and $C$. vrystaatense. Syst. Appl. Microbiol., 37(5):342-350. http://dx.doi.org/10.1016/j.syapm.2014.04.004

Nemli, S.A., Demirdal, T., Ural, S., 2015. A case of healthcare associated pneumonia caused by Chryseobacterium indologenes in an immunocompetent patient. Case Report. Infect. Dis., 2015:483923. http://dx.doi.org/10.1155/2015/483923

O'Hara, C.M., 2006. Evaluation of the Phoenix 100 ID/AST system and NID panel for identification of Enterobacteriaceae, Vibrionaceae, and commonly isolated nonenteric Gram-negative bacilli. J. Clin. Microbial., 44(3):928-933. http://dx.doi.org/10.1128/JCM.44.3.928-933.2006

Park, Y.J., Son, H.M., Lee, E.H., et al., 2013. Chryseobacterium gwangjuense sp. nov., isolated from soil. Int. J. Syst. Evol. Microbiol., 63(Pt 12):4580-4585. http://dx.doi.org/10.1099/ijs.0.052118-0

Sambrook, J., Russell, D.W., 2001. Molecular Cloning: A Laboratory Manual, 3rd Ed. Cold Spring Harbor, NY.

Sharma, P., Gupta, S.K., Diene, S.M., et al., 2015. Wholegenome sequence of Chryseobacterium oranimense, a colistin resistant bacterium isolated from a cystic fibrosis patient in France. Antimicrob. Agents Chemother., 59(3):
1696-1706.

http://dx.doi.org/10.1128/AAC.02417-14

Shimomura, K., Kaji, S., Hiraishi, A., 2005. Chryseobacterium shigense sp. nov., a yellow-pigmented, aerobic bacterium isolated from a lactic acid beverage. Int. J. Syst. Evol. Microbiol., 55(5):1903-1906.

http://dx.doi.org/10.1099/ijs.0.63690-0

Skerman, V.B.D., 1967. A Guide to the Identification of the Genera of Bacteria, 2nd Ed. Williams \& Wilkins Co., Baltimore.

Smibert, R.M., Krieg, N.R., 1994. Phenotypic characterization. In: Gerhardt, P., Murray, R.G.E., Wood, W.A., et al. (Eds.), Methods for General and Molecular Bacteriology, American Society for Microbiology. Washington, DC, p.607-653.

Stackebrandt, E., Frederiksen, W., Garrity, G.M., et al., 2002. Report of the ad hoc committee for the re-evaluation of the species definition in bacteriology. Int. J. Syst. Evol. Microbiol., 52(3):1043-1047. http://dx.doi.org/10.1099/00207713-52-3-1043

Tamura, K., Stecher, G., Peterson, D., et al., 2013. MEGA6: Molecular Evolutionary Genetics Analysis Version 6.0. Mol. Biol. Evol., 30(12):2725-2729. http://dx.doi.org/10.1093/molbev/mst197

Thompson, J.D., Gibson, T.J., Plewniak, F., et al., 1997. The CLUSTAL_X windows interface: flexible strategies for multiple sequence alignment aided by quality analysis tools. Nucleic Acids Res., 25(24):4876-4882. http://dx.doi.org/10.1093/nar/25.24.4876

Tindall, B.J., 1990. Lipid composition of Halobacterium lacusprofundi. FEMS Microbiol. Lett., 66(1-3):199-202. http://dx.doi.org/10.1111/j.1574-6968.1990.tb03996.x

Vandamme, P., Bernardet, J.F., Segers, P., et al., 1994. New perspectives in the classification of the flavobacteria: description of Chryseobacterium gen. nov., Bergeyella gen. nov., and Empedobacter nom. rev. Int. J. Syst. Bacteriol., 44(4):827-831. http://dx.doi.org/10.1099/00207713-44-4-827

Wang, S.L., Liang, Y.C., Liang, T.W., 2011. Purification and characterization of a novel alkali-stable $\alpha$-amylase from Chryseobacterium taeanense TKU001, and application in antioxidant and prebiotic. Process Biochem., 46(3): $745-750$ http://dx.doi.org/10.1016/j.procbio.2010.11.022

Wen, C., Xi, L., She, R., et al., 2016. Lysobacter chengduensis sp. nov. isolated from the air of captive Ailuropoda melanoleuca enclosures in Chengdu, China. Curr. Microbiol., 72(1):88-93. http://dx.doi.org/10.1007/s00284-015-0921-8

Xie, C.H., Yokota, A., 2003. Phylogenetic analysis of Lampropedia hyalina based on the 16S rRNA gene sequence. J. Gen. Appl. Microbiol., 49(6):345-349. http://dx.doi.org/10.2323/jgam.49.345

$\mathrm{Xu}, \mathrm{X} . \mathrm{W} ., \mathrm{Wu}, \mathrm{M} ., 2$ 2005. Isolation and characterization of a novel strain of Natrinema containing a bop gene. J. Zhejiang Univ.-Sci. B (Biomed. \& Biotechnol.), 6(2): 
$142-146$.

http://dx.doi.org/10.1631/jzus.2005.B0142

Yang, F., Liu, H.M., Li, S.P., et al., 2015. Chryseobacterium shandongense sp. nov., isolated from soil. Int. J. Syst. Evol. Microbiol., 65(6):1860-1865.

http://dx.doi.org/10.1099/ijs.0.000186

\section{List of electronic supplementary materials}

Fig. S1 Transmission electron micrograph of a negatively stained cell of strain $25-1^{\mathrm{T}}$, showing the absence of flagella

\section{中文概要}

题 目: 分离自成都大熊猫兽舍空气中的一株金黄杆菌属 新种的鉴定
目 的: 鉴定菌株 $25-1^{\mathrm{T}}$ 是否是金黄杆菌属的一个新种。 创新点：首次从空气中分离到金黄杆菌属的新种。

方 法: 革兰氏染色镜检; 磷铇酸染色然后透射电镜观察 菌株 25-1 ${ }^{\mathrm{T}}$ 形态结构; 全自动生理生化鉴定系统 (Phoenix ${ }^{\mathrm{TM}}-100$ ) 与传统生理生化反应管相结 合; H890 气象色谱仪进行脂肪酸组分分析; 薄 板双相层析进行极性脂组分分析; 反相高压液相 色谱分析法进行呼吸琨组分分析; 熔解温度法检 测 G+C 摩尔含量; 16S rRNA 序列测定及系统发 生分析。

结 论: 根据传统特征分类研究结果 (形态特征、培养特 性和生理生化特征) 、化学分类研究结果 (脂肪 酸组分、极性脂组分和呼吸琨组分) 和遗传特征 分类研究结果 $(\mathrm{G}+\mathrm{C}$ 摩尔含量、DNA 同源性测 定和 16S rRNA 序列测定及系统发生分析) 得出 菌株 $25-1^{\mathrm{T}}$ 为金黄杆菌属的一个新种。

关键词: 成都源金黄杆菌; 大熊猫; $16 \mathrm{~S}$ rRNA 测序; 系 统发育树分析; 菌株 $25-1^{\mathrm{T}}$ 